\title{
Vegetation and water yield dynamics in an Edwards Plateau watershed
}

\author{
X. BEN WU, ERIC J. REDEKER, AND THOMAS L. THUROW
}

Authors are assistant professor, Department of Rangeland Ecology and Management, Texas A\&M University, College Station, Tex. 77843; research scientist, Caesar Kleberg Wildlife Research Institute, Texas A\&M University-Kingsville, Kingsville, Tex. 78363; and professor and head, Department of Renewable Resources, University of Wyoming, Laramie, Wyo. 82071.

\begin{abstract}
Woody cover, when expressed at the scale of the $207 \mathrm{~km}^{2}$ Cusenbary Draw basin, remained unchanged ( 23\%) from 1955 to 1990 . When expressed at the scale of range sites, woody cover declined on sites with relatively high production potential and increased on sites with relatively low production potential. Change in woody cover distribution at sub-range site scales, increased low and high woody covers and decreased intermediate woody cover, would be expected to lead to increased water yield at the basin scale because there was an apparent threshold woody cover $(\sim 20 \%)$ above which simulated evapotranspiration (ET) changed little with increasing woody cover. This potential increase, however, was more than offset by the decreased water yield due to increased ET loss associated with compositional changes of woody vegetation from oak to juniper. A set of woody cover-ET regression curves was developed for different range sites based on simulation studies using the SPUR-91 hydrologic model. Based on these woody cover-ET regression curves and GIS analysis, no brush management would result in a $35 \%$ decrease in water yield, while a hypothetical brush management cost-share program would increase water yield by $43 \%$ over the 1990 level. Benefits in water yield and forage production from brush management differ in different range sites. A brush management cost-share program that preferentially allocated brush management to sites with deep soil and the highest forage production potential increased water yield by $50 \%$, compared to a $100 \%$ increase if brush management were preferentially allocated on sites with shallow soil and highest water yield potential. These model results illustrate that the spatial scale of assessment and spatial distribution of brush management among range sites should be important concerns associated with developing and evaluating brush management policies.
\end{abstract}

Key Words: brush management, evapotranspiration, GIS and remote sensing, hydrologic modeling, semi-arid rangeland

Replacement of grasslands and savannas with woodlands is a worldwide trend that coincided with European expansion and settlement in the eighteenth and nineteenth centuries (Scholes and

The research was supported by a grant from the Texas Agriculture Experiment Station. The authors wish to thank Fred Smeins, Charles Taylor, Dee Carlson, Tom Payton, Shiping Xiong, Xiaolian Ren, and Carr Thomson for their assistance during the study. Comments of Fred Smeins and 2 anonymous reviewers led to considerable improvement of the manuscript.

Manuscript accepted 19 Jun. 2000.

\section{Resumen}

Cuando la cobertura de la vegetación leñosa se expresó a escala de los $207 \mathrm{~km}^{2}$ de la cuenca Cusenbary Draw permaneció sin cambios $(\sim 23 \%)$ durante el periodo de 1955 a 1990 . Cuando se expresó a escala de sitio de pastizal, la cobertura de leñosas disminuyó en sitios con potenciales de producción relativamente altos y se incrementó en sitios con potenciales de producción relativamente bajos. Por los cambios en la distribución de la cobertura de leñosas a escala de subsitio de pastizal (aumento en la cobertura de leñosas bajas y altas y disminución en la de leñosas intermedias) se esperaría que ocurriera un aumento en el rendimiento de agua a nivel de cuenca, porque aparentemente hubo un umbral de cobertura de leñosas $(\sim 20 \%)$ arriba del cual la evapotranspiración simulada (ET) cambia poco con los aumentos de cobertura de leñosas. Sin embargo, este incremento potencial fue mas que compensado por la disminución en el rendimiento de agua debido a el incremento de la perdida de ET asociada con los cambios composicionales de la vegetación de leñosas de roble a juniper. Se desarrollo un juego de curvas de regresión entre coberturas de leñosas y ET para diferentes sitios de pastizal, las curvas se desarrollaron en base a estudios de simulación utilizando el modelo hidrológico SPUR-91. Basados en estas curvas de regresión y análisis con sistemas de información geográfica, el no manejar la vegetación arbustiva resultaría en una disminución del $35 \%$ del rendimiento de agua, mientras que un programa de manejo de los arbustos, hipotéticamente viable en términos de costos, incrementaría el rendimiento de agua en $43 \%$ respecto a la producción de 1990 . Los beneficios en rendimiento de agua y producción de forraje difieren entre sitios de pastizal distintos. Un programa de manejo de arbustos económicamente viable asignado a sitios de pastizal con suelo profundo y la mas alta de producción de forraje incrementaría el rendimiento de agua en $\mathbf{5 0 \%}$, comparado con el incremento del $100 \%$ si el manejo de arbustos se asignará a sitios con suelos poco profundos y con el mayor potencial de rendimiento de agua. Los resultados de este modelo ilustran que la evaluación de la escala espacial y la distribución espacial del manejo de arbustos entre sitios de pastizal deben ser preocupaciones importantes asociadas al desarrollo y evaluación de las políticas de manejo de arbustos.

Archer 1997). This shift from grassland savannas to shrub-dominated landscapes has broad implications for availability and quality of water (Archer 1994, Thurow 1998). Increased woody cover and its effect on hydrology have special significance in the semiarid rangelands of the western US that are relied on as sources of 
water, such as the Edwards Plateau region of Texas. The Edwards aquifer, which is recharged from Edwards Plateau rangelands, is the primary source of water for San Antonio, Austin and the many other municipalities of the region. Many rivers also originate in this region, which provide habitat for endangered species, recreational opportunities, and water supply to an area extending from the Edwards Plateau to the Gulf Coast.

Policy makers are increasingly concerned that vegetation management on rangeland be responsive to regional water yield objectives (Thurow et al. 2000). Water yield (deep percolation and surface runoff) from rangelands can be determined by the balance of water input in precipitation and water output in evapotranspiration (interception loss, soil evaporation, and transpiration), plus any changes in the amount of water stored in soil (Hibbert 1983). In semi-arid rangelands, evapotranspiration (ET) can account for $80-95 \%$ of the water loss (Thurow 1991). Changes in woody cover in semi-arid rangelands can significantly alter ET losses, hence water yield, due to higher interception and transpiration of woody vegetation compared to those of herbaceous vegetation, particularly on shallow range sites. Annual interception loss, mainly determined by precipitation pattern and the water holding capacity of plant canopies and associated litter, ranges from 11 to $18 \%$ of precipitation for herbaceous vegetation (Clark 1940, Thurow et al. 1987) and is considerably higher for woody vegetation [e.g., about $46 \%$ for live oak (Thurow et al. 1987) and 70 to $80 \%$ for juniper (Eddleman 1983, Hester 1996)]. Most woody plants in semiarid rangelands also have higher transpiration rates than do grasses and forbs due to larger transpirational area (leaf area), longer transpirational period (length of growing period), and deeper rooting structures that access deep soil moisture (Davis and Pase 1977, West 1992). Studies at plot (1 to $20 \mathrm{~m}^{2}$ ) and catchment (1 to $10 \mathrm{ha}$ ) scales have shown that reduction of woody cover through brush management on the Edwards Plateau area significantly increases water yield, mostly as deep drainage to recharge springs and aquifers because of the high infiltration characteristics of Edwards Plateau soils and the fractured limestone substrate (Richardson et al. 1979, Dugas et al. 1996, Thurow and Hester 1997).

A number of catchment experiments have been conducted on rangeland and forest watersheds to determine the effect of vegetation changes on ET and water yield (summarized by Bosch and Hewlett 1982, Hibbert 1983, Douglass 1983). Catchment level water yield studies are very expensive and frequently require many years before a conclusion can be drawn, consequently empirical studies can only evaluate a very limited number of sites and vegetation management scenarios. A potentially effective approach for assessing the effect of brush management on water yield in large watersheds is computer simulation using watershed hydrologic models (Singh 1995). One such model is the SPUR-91 (Simulation of Production and Utilization of Rangelands), a physically-based simulation model that has been specifically developed and validated for rangeland ecosystems (Wight and Skiles 1987, Carlson and Thurow 1992, 1996). One limiting factor for this approach is the requirement of complex input parameters of spatially distributed attributes. The development of geographic information systems (GIS) technology and spatial modeling approaches in the recent decades has significantly eased this limitation and made the application of complex hydrology models practical (Maidment 1993). Another factor that limits the usefulness of hydrologic modeling approaches for assessment of the effects of brush management on water yield is spatially explicit vegetation data with sufficient spatial resolution and extent suitable for both brush management assessment and hydrologic modeling. Remote sensing and digital image processing technologies have made the development of such vege- tation data covering large spatial and temporal extents possible, although it requires a considerable amount of time and effort.

Objectives of this study were to 1) assess historical (1955 to 1990) changes in vegetation structure and its relationship to rangeland management, using remote sensing and GIS analysis, in a $207 \mathrm{~km}^{2}$ watershed composed of 5 range sites representative of the rangelands on the western Edwards Plateau, and 2) develop predictive vegetation structure and water yield relationships using SPUR-91 hydrologic model simulations and GIS modeling to evaluate a) the effect of changing woody cover, as well as the spatial scale of assessment, on water yield, and b) the water yield ramifications of brush management patterns and policies.

\section{Materials and Methods}

\section{Study Area and GIS Database}

The study was conducted on the Cusenbary Draw basin $\left(207 \mathrm{~km}^{2}\right)$ on the Edwards Plateau $\left(30^{\circ} 21^{\prime} \mathrm{N} ; 100^{\circ} 38^{\prime} \mathrm{W}\right)$ (Fig. 1). The elevation of the basin ranges from 628 to $711 \mathrm{~m}$ above msl. The mean frost-free period is 240 days. Annual precipitation is highly variable with a mean of $553 \mathrm{~mm}$ and a range of 156-1,054 $\mathrm{mm}$. Most precipitation results from intense, brief thunderstorms. Low Stony Hill and Shallow range sites are the most common range sites within the basin; Deep Divide, Valley and Bottomland range sites are also present (Fig. 1). Tarrant stony clay,

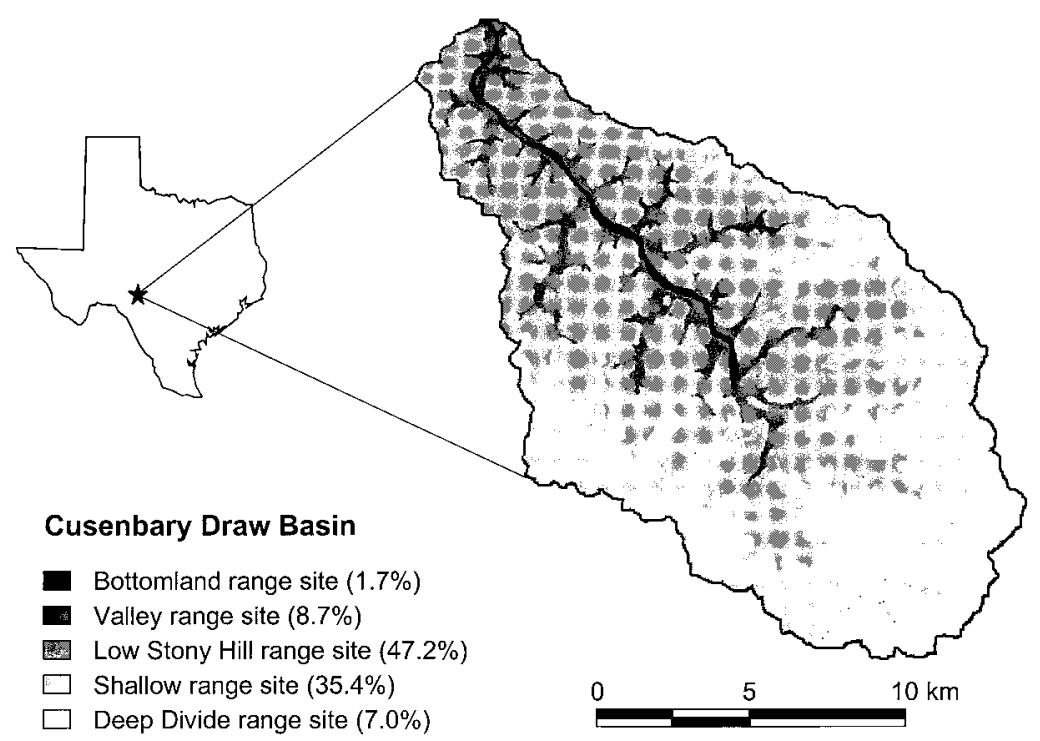

Fig. 1. Study site showing the location of the Cusenbary Draw basin and range sites in the basin. Percentage in parentheses indicates proportion of the basin in a range site. 
Kavett-Tarrant complex, Tobosa clay, Knippa silty clay and the Frio-Dev association characterize the soils within these range sites, respectively (Wiedenfeld and McAndrew 1968). Woody vegetation composition varies considerably among sites. Ashe and redberry juniper (Juniperus ashei Buchh. and Juniperus pinchotii Sudw.), live oak (Quercus virginiana Mill.), and Vasey shin oak ( $Q$. pungens var. vaseyana Buckholz) dominate the shallow soil upland sites with honey mesquite (Prosopis glandulosa Torr.) and live oak dominating the sites with deeper soil. Dominant herbaceous species include Texas wintergrass (Stipa leucotricha Trin. \& Rupr.), sideoats grama (Bouteloua curtipendula Torr.), three-awn (Aristida purpurea Nutt.), and common curlymesquite (Hilaria belangeri Nash) (Fuhlendorf and Smeins 1997).

A GIS database was developed for the study area. The watershed boundaries of the Cusenbary Draw basin and its subwatersheds were delineated based on the 1:24000 digital elevation models (DEM) through cell-based hydrologic modeling using ARC/INFO GRID (ESRI 1994). Over 300 ground control points were distributed throughout the basin and immediate surrounding areas; geo-location data for these points were collected using Trimble's Pathfinder global positioning system (GPS) units ( $\pm 2.5-\mathrm{m}$ accuracy). Range sites were delineated from 1:20000 NRCS soils maps from the Sutton County Soil Survey (Wiedenfeld and McAndrew 1968). These soils maps were scanned into digital format, mosaicked using ERDAS Imagine (ERDAS 1997), and geo-referenced with the GPS control points using a secondorder polynomial transformation (Fig. 1).

\section{Changes in Vegetation Structure}

Historical vegetation coverage was developed from over 90 black and white aerial photographs taken in 1955 (1:20,000) and $1990(1: 40,000)$. The photos were scanned into digital form with $1-\mathrm{m}$ resolution (1- $\mathrm{m}^{2}$ pixels); mosaicked and geo-referenced based on GPS ground control points using ERDAS Imagine. An iterative self-organizing clustering algorithm (ERDAS ISODATA) (ERDAS 1997) was used to classify the images by range site. Fifty clusters generated by the algorithm were then reclassified into 2 classes, woody and non-woody, based on original aerial photographs and field verification. A 50x50-m moving window with $10-\mathrm{m}$ steps was used to evaluate the spatial distribution of woody cover in different range sites. The composition of the vegetation in each range site was estimated based on data from the literature (Smeins and Merrill 1988, Wiedenfeld and McAndrew 1968, Thurow et al. 1988, Schacht and Reinke 1993, Hester 1996). Seven compositional classes including juniper, oak, mesquite, shortgrass, midgrass, forbs, and bare ground were used for simulation modeling.

\section{Effect of Woody Cover on Water Yield}

The effects of woody cover on water yield were examined through simulations using the SPUR-91 hydrologic model (Carlson and Thurow 1992). This model was validated on several Texas rangeland sites, including the Sonora Agricultural Experiment Station site which was part of the Cusenbary Draw basin. The model has proven to be effective in predicting the effect of management practices on hydrology (Carlson and Thurow 1996). A single climate input file, generated based on average monthly precipitation data (1948 to 1996), was used for all simulations. The generated precipitation data were adjusted by subtracting interception that was determined based on the percent cover and species composition of the vegetation in each range site and the species-specific interception data from the literature (Clark 1940, Thurow et al. 1987, Desai 1992, Thurow and Hester 1997) since SPUR-91 did not take interception into account. The phytomass for each site was estimated based on the vegetation composition and species-specific phytomass parameters from the SPUR-91 Texas validation input files (Carlson and Thurow 1992). Simulations were conducted for nine $\sim 10 \%$ increments from 0 to $80 \%$ of potential woody cover for each of the range sites based on 1990 species composition (Fuhlendorf and Smeins 1997, Unpublished data, Smeins and Fuhlendorf). The species compositions was defined by the proportion of woody cover that were juniper, oaks, and mesquite and the proportion of non-woody cover that were short-grass, mid-grass, forbs, and bare ground for each of the range sites (Redeker 1998). These compositions were used for simulations with different percent woody cover. Each simulation was run for 15 years and only the last 10 years of data were used for analysis, which increases the reliability of simulation results by allowing the sensitive parameters to stabilize (Carlson and Thurow 1992). Results of the simulations for the nine, 0 to $80 \%$ woody cover levels, were used to generate regression curves of percent woody cover vs. ET for each of the range sites. A form of exponential curve was fitted to the data with non-linear regression using the Levenberg-Marquardt algorithm. Evapotranspiration for each range site was estimated based on the proportions of land (in 0.25 ha cells) in $5 \%$ woody cover intervals and the woody cover-ET curve for that range site. The ET for the entire basin was determined as a weighted average of the range site estimates. Running the simulation by range site using the field scale model may underestimate the ET for the Valley and Bottomland range sites because there may be additional water input from surface and subsurface flows from the upland sites. Given the shallow soil and fractured limestone substrate of the uplands, however, it is likely that the majority of the water input from upland would be in channel, and possibly spring, flow which may affect only a limited proportion of the Valley and Bottomland range sites. Water yield was estimated as the difference between simulated annual precipitation and predicted total ET, assuming no longterm changes in water stored in soil. Although changes in water stored in soil $(\Delta S)$ can be an important factor for eventbased simulation and time specific shortterm evaluations, in assessing long-term average behavior for strategic evaluation and planning, however, it should be reasonable to assume $\Delta \mathrm{S}=0$.

\section{Water Yield Ramifications of Brush Management}

The woody cover-ET regression curves were used to assess the effect of vegetation on water yield under different management scenarios. For a scenario of zero brush management, 2 areas in the basin that received no brush management from 1955 to 1990 , one on a deep soil range site and the other on a shallow soil range site, were used to estimate the relative change in percent woody cover in the absence of brush management. The relative change in woody cover of the deep range site was used for the Bottomland, Valley and Deep Divide range sites where the primary invading species is honey mesquite. The relative change in woody cover of the shallow site was used for the Shallow and Low Stony Hill range sites where the primary invading species is juniper. In the second scenario, the effects of a Texas brush management program that incorporated a revenue neutral cost-share offer (Thurow et al. 2000) were examined. This study found that $40 \%$ of the rangeland would be voluntarily enrolled in a publicly funded brush management program designed to increase water yield that 
required that woody cover be reduced to $3 \%$ via chaining on all land entered into the program. For this simulation, woody cover was reduced to $3 \%$ on $40 \%$ of the land in each range site, and was held at the 1990 level in the remaining $60 \%$ of the land. The third and fourth scenarios were variations of the second scenario with different spatial distributions of the enrolled land; one concentrated the brush management on the range sites that had the greatest potential for forage production and the other concentrated the brush management on the range sites that had the greatest potential for water yield.

\section{Results and Discussions}

\section{Changes in Vegetation Structure}

The overall woody cover remained virtually unchanged $(23.6 \%)$, when expressed at the scale of the $207 \mathrm{~km}^{2}$ Cusenbary Draw basin. However, changes in woody cover varied considerably among different range sites over the 35 years based on the classified 1955 and 1990 aerial photography (Fig. 2). This is largely due to the uneven distribution of brush management efforts (Redeker et al. 1998). The majority of the brush management took place on range sites with higher production potential because investment in clearing brush on these sites offers higher economic returns in terms of increases in forage. As a result, woody cover decreased $17 \%$ and $28 \%$, respectively, in the most productive Bottomland and Valley range sites while it increased over $170 \%$ in the least productive Deep Divide sites.
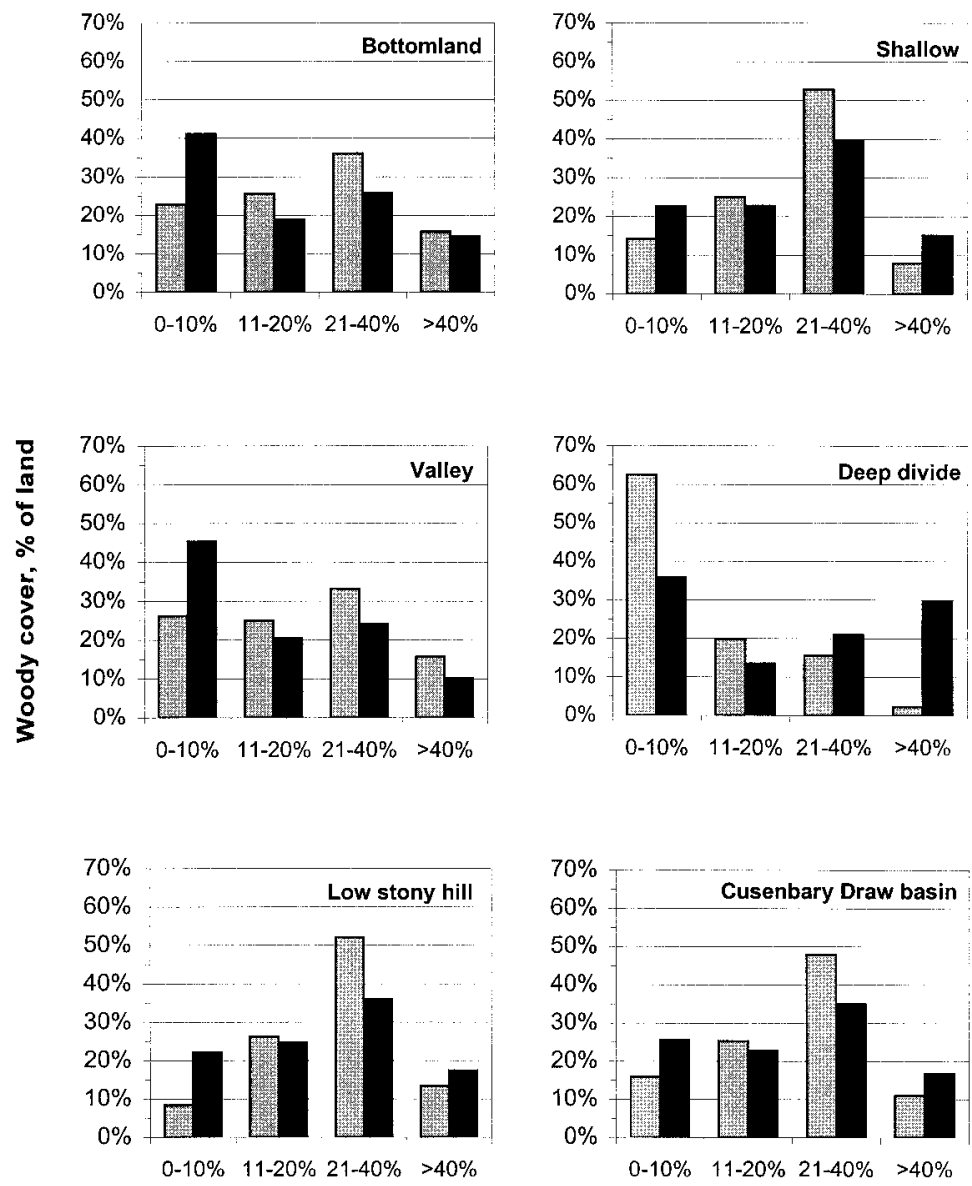

Percent woody cover class

말 $1955 \square 1990$

Fig. 3. Distribution of areas with different percent woody cover for individual range site and the whole basin in 1955 and 1990.

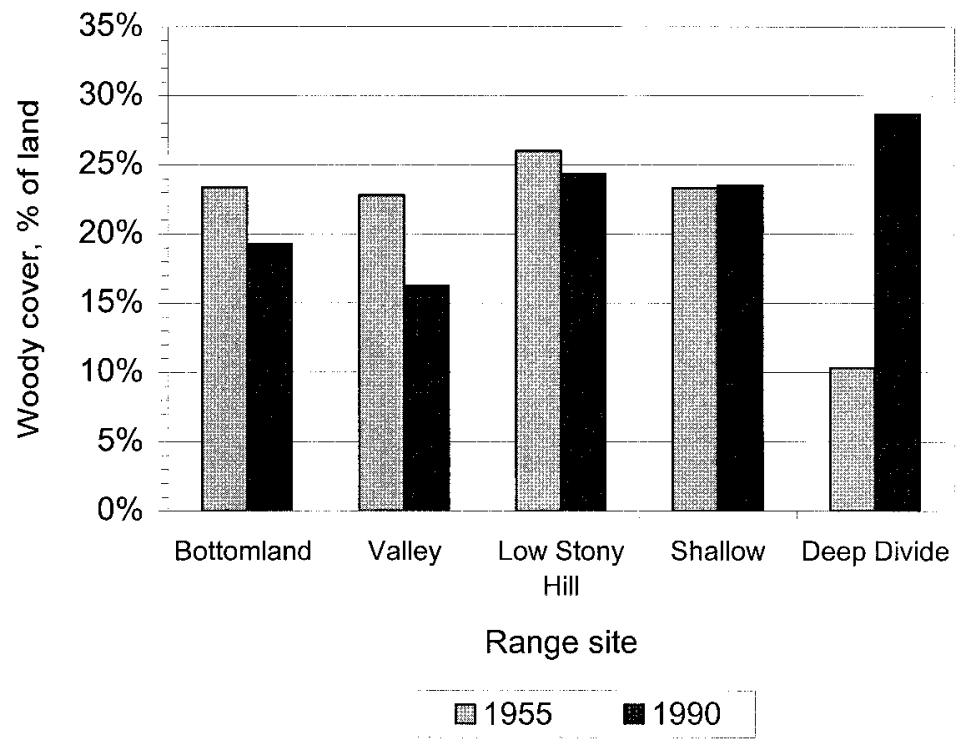

Fig. 2. Percent cover of woody vegetation for individual range site in 1955 and 1990.
Changes in the relative amount of land with different amount of woody cover in each range site further illustrate the dynamics in woody encroachment and brush management (Fig. 3). On the most productive Bottomland and Valley range sites, considerable amount of land with medium $(11-40 \%)$ and high $(>40 \%)$ woody covers were converted to areas with low woody cover $(\leq 10 \%)$. The proportion of land with low woody cover on these range sites increased to over $40 \%$ by 1990 , some 70 to $80 \%$ increase over the 35 years. On Low Stony Hill and Shallow range sites with intermediate forage production potentials, considerable brush management increased the proportion of land with low woody cover to over $20 \%$; however, woody encroachment in some other areas was not controlled which resulted in an increase in the area of land with high woody cover. Due to low levels 
of brush management efforts, the area with low woody cover decreased from $62 \%$ to $36 \%$ for the least productive Deep Divide range site, while the area with high woody cover increased from less than $3 \%$ to near $30 \%$. As a result of these changes, there was an increase in the amount of land with either low or high woody cover at the expense of a decreasing amount of land with intermediate woody cover in the Cusenbary Draw basin as a whole. This change in the distribution reflected a combination of accelerated rates of woody encroachment and unevenly distributed brush management efforts.

Although the vegetation composition on the deeper range sites remained unchanged over the 35 years, there was a significant reciprocal change in juniper and oak cover on the Low Stony Hill and Shallow range sites. Juniper cover increased from $2.9 \%$ in 1955 to $10.9 \%$ in 1990 , while oak cover decreased from $18.3 \%$ to $9.9 \%$ in the same period. Two factors contributed most to this shift in woody vegetation structure. The severe drought in the 1950's resulted in high mortalities of woody species, but the mortality for juniper trees less than 2$m$ tall was insignificant (Merrill and Young 1959). This set the stage for juniper to increase its cover in the years after the drought with the absence of fire (Fuhlendorf et al. 1996). The other factor contributing to this increase in juniper was the chaining practices common in the 1950 's and 1960's that indiscriminately cleared all brush. Redberry juniper aggressively coppices from the roots. It is likely that the continuous presence of cattle, sheep, goats and deer would have put greater browse pressure on the resprouts and seedlings of oaks than on the less palatable juniper seedlings and resprouts.

\section{Effect of Woody Cover on Water Yield \\ Woody Cover-ET Relationship}

The woody cover-ET regression curves based on the systematic simulation studies represent the effect of woody cover on water balance for each of the 5 range sites within the Cusenbary Draw basin which are representative of the rangelands on the Edwards Plateau (Fig. 4). Evapotranspiration, the reciprocal of water yield, often accounts for over $90-95 \%$ of the water budget on these rangelands and the reduction of ET is the key for vegetation management to increase water yield (runoff and deep percolation). Deeper range sites (Bottomland and Valley) exhibit relatively little change in ET with changes in woody cover. This is due to the high ET at $0 \%$ woody cover determined by the soil depth and large amount of herbaceous transpiring tissue, and the low interception losses associated with honey mesquite which tends to dominate these sites. On the Low Stony Hill and Shallow range sites, ET increases dramatically with increase in woody cover over $0 \%$ as a result of elevated interception loss of precipitation by juniper and oak. With continuous deep soil, relatively high herbaceous cover and greater component of mesquite in the woody cover, the upland Deep Divide range sites have relatively small change in ET with changes in woody cover.

These simulation results compared favorably with the literature. The model predicted ET losses within $5 \%$ of values reported in the studies of Thurow and Hester (1997) based on empirical field
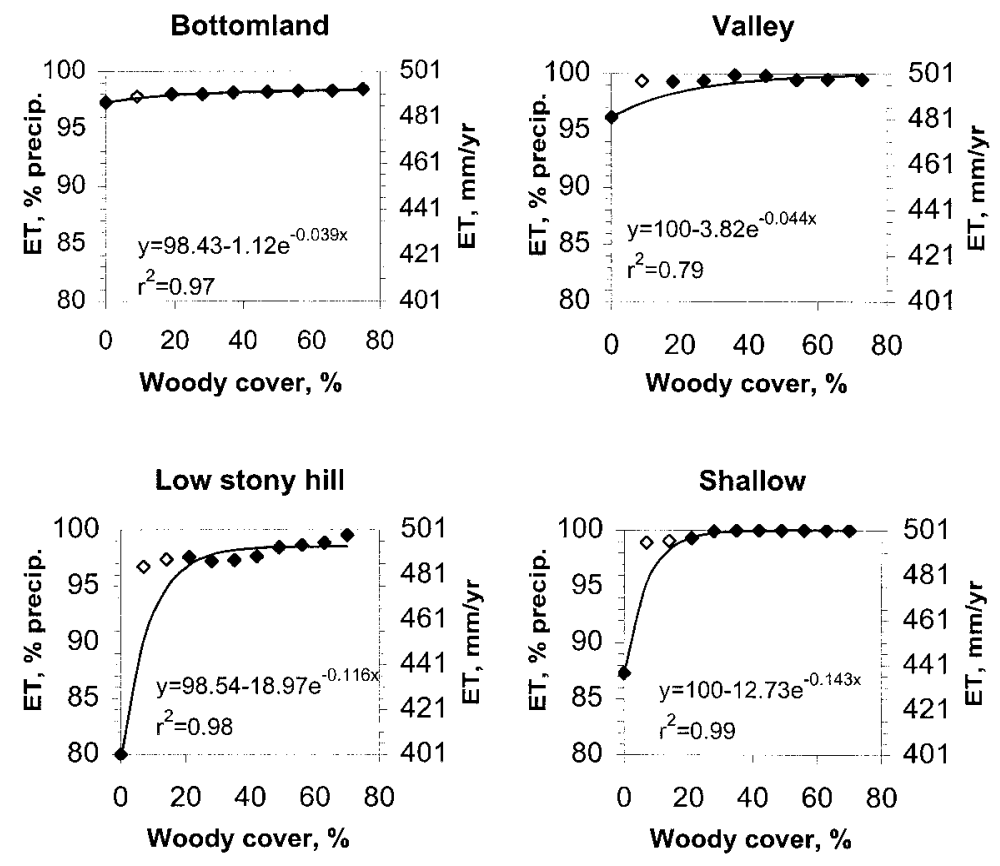

studies conducted on a Shallow range site at the Sonora Agriculture Experiment Station. The simulation results fit well to the experimental studies not only at $0 \%$ woody cover, where very high reliability was demonstrated in the validation studies (Carlson and Thurow 1992), but also at high woody cover levels. The SPUR-91 model simulations predicted $5 \%$ greater ET than the empirical estimates on $100 \%$ herbaceous cover, $2 \%$ greater on $30 \%$ woody cover and less than $1 \%$ greater on $60 \%$ woody cover. These similar results of 2 very different methods strengthen the case that these estimates are reasonable for the region.

The simulations, however, apparently over-predict ET at low but non-zero woody cover levels. The SPUR-91 model performs well in situations with no $(0 \%)$ 
woody cover or with relatively high (>20\%) woody cover, but not in situations with relatively low ( $<20 \%$ ) woody cover. The soil moisture extraction routine of the model allows plants to extract their physiologic requirements of water before allowing soil water to percolate below their rooting zone. When a single woody plant is present on a site the model does not limit water extraction for that plant to the volume of soil physically accessible to the plant. Rather this plant is allowed unlimited access to all soil water on the site that has percolated below the maximum rooting depth of more shallow rooted herbaceous species. This lack of spatial constraints on soil water available for individual woody plants allows unrealistic luxury consumption that results in an over-prediction of transpiration in low woody cover scenarios. This over-prediction in low woody cover conditions can be compensated for by fitting a form of exponential curves to the data points generated by the model, excluding the data points at very low $(<15 \%)$ but non-zero woody covers. These regression curves fit the data points at $0 \%$ and high woody cover well while reducing the effects of excessive water extraction in low woody cover conditions. An ET to woody cover regression curve for the Cusenbary Draw basin was generated based on the regression curves for individual range sites and the relative proportions of the basin fall in different range sites (Fig. 4).

\section{Woody Cover and Water Balance}

Figure 5 depicts the water balance of the Cusenbary Draw basin as a function of percent woody cover, based on the simulation results with 1990 species composition and associated regression curves. Interception loss increases linearly with increasing woody cover assuming the species composition remains unchanged. The amount of bare ground may increase on Shallow and Low Stony Hill ranges, sites dominated by dense stands of juniper and oak thereby lowing the interception loss of the area not occupied by woody cover. This should have a limited influence on the estimation of interception given the small amount of non-woody cover and the relatively low interception of herbaceous species. For example, an increase in the proportion of bare ground in the non-woody cover from the default $30 \%$ to $80 \%$ would change the interception from $50.4 \%$ to $49.3 \%$ on Shallow and Low Stony Hill ranges sites with $80 \%$ woody cover. Soil evaporation is greatest at $0 \%$ woody cover and decreases as woody cover increases due to the modifi-
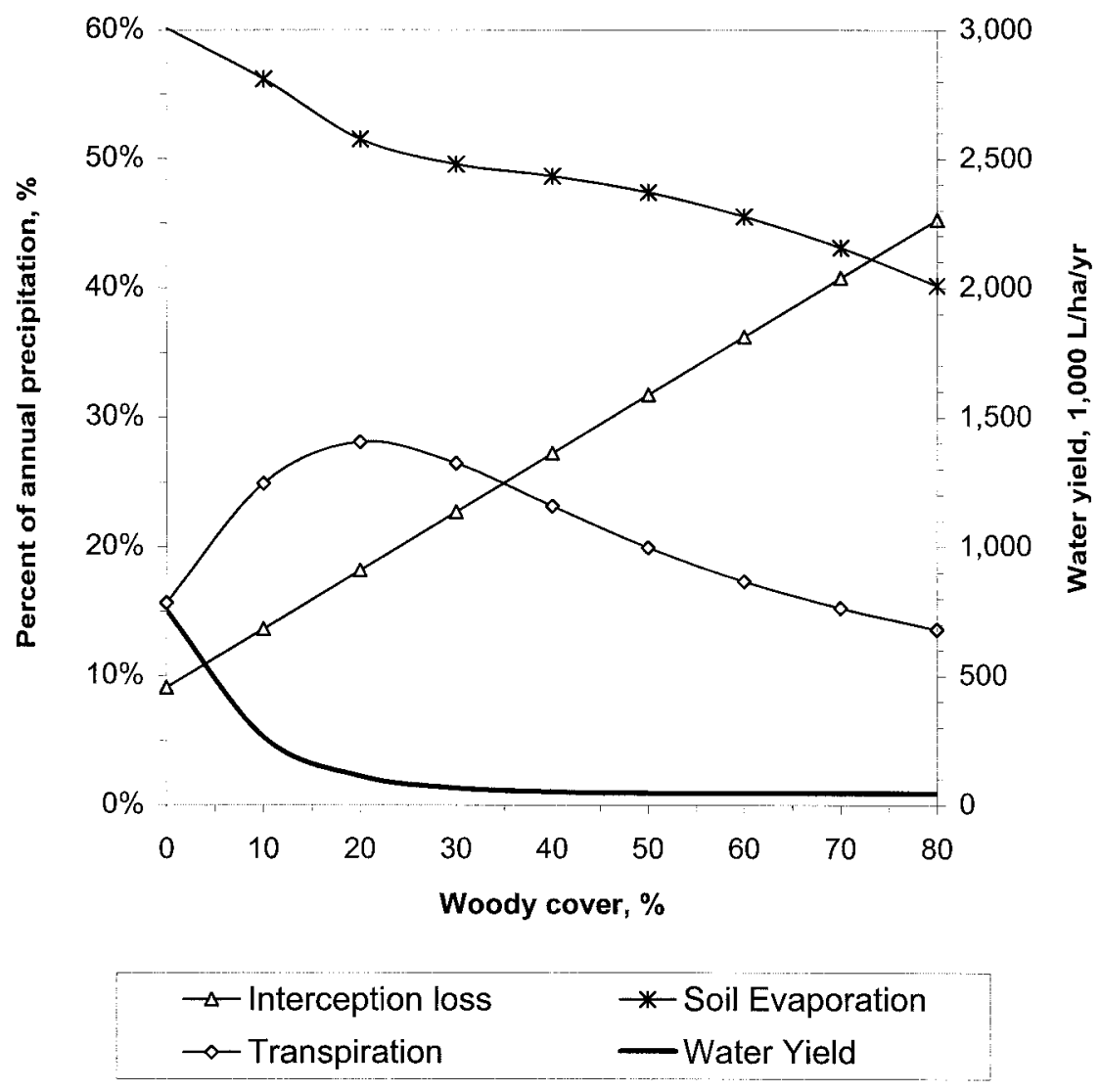

Fig. 5. Water balance for the Cusenbary Draw basin.

cation of microenvironments by increased shading and reduced wind exposure (Thurow and Hester 1997). The rate of reduction in soil evaporation decreases at woody covers greater than $20 \%$. Transpiration initially increases with increased woody cover. As woody cover increases beyond $20 \%$, however, transpiration begins to decrease in response to the reduced amount of precipitation reaching mineral soil, hence reduced soil water available for transpiration, as a result of increased interception loss. These modeling results indicate that there is a threshold woody cover around $20 \%$ over which the reduction of water yield levels off and water yield reaches its lowest level. Below this threshold woody cover, water yield increases exponentially with decreasing woody cover. This implies that brush management effort must reduce the woody cover to less than $20 \%$ to have a meaningful contribution to water yield on these rangelands. It also shows that the lower the woody cover the more effective per unit reduction of woody cover for increased water yield.
Effect of Spatial Scale on Assessment of Vegetation Change and Water Yield

Given the differential changes in woody cover on different range sites (Fig. 2) and the different shapes of the woody coverET regression curves for different range sites (Fig. 4), it would be misleading to use the average woody cover and the woody cover-ET regression curve for the basin to assess the effect of vegetation change from 1955 to 1990 on water yield. Even assessments based on average woody cover and woody cover-ET regression curve for individual range sites may be inaccurate because of the strongly nonlinear nature of the woody cover-ET regression curves (Fig. 3). An area dominated by an intermediate level of woody cover would have lower water yield than an area with the same average woody cover but dominated by very low and very high woody covers. These considerations illustrate that assessments should be based on frequency distribution of areas with different percent woody cover by range sites. If the woody species composition in 1955 were the same as that in 1990 , the changes in woody cover distribution from 1955 to 1990 would have resulted in a 
$24 \%$ increase in water yield. However, water yield from Cusenbary Draw basin actually decreased (over $30 \%$ ) because of the reciprocal change in juniper and oak cover on the Low Stony Hill and Shallow range sites and the higher interception and transpiration rates of juniper compared to that of oak (Thurow et al. 1987, Owens 1996, Thurow and Hester 1997). Despite improvement in woody cover distribution from the efforts of brush management over the 35 years, the potential increase in water yield, however, was more than offset by the decreased water yield due to compositional changes of woody vegetation caused in part by brush management practices.

\section{Water Yield Ramifications of Brush Management}

The hydrologic modeling approach used in this study and the resulting woody cover-ET regression curves can be an effective tool for assessing the implications of brush management scenarios for policy making and educational purposes. In the absence of landowner investment in brush management, the amount of woody cover would increase substantially as was evident on several ranches within the basin that selected not to invest in this form of land management. With no brush management, the Shallow and Low Stony Hill sites were observed to experience over $50 \%$ relative increases in woody cover from 1955 to 1990; and the Deep Divide, Bottomland, and Valley range sites were observed to experience relative increases in woody cover as high as $150 \%$. Such increase in woody cover will result in a significant change in water yield. A scenario of no brush management, assuming a $5 \%$ increase in woody cover for the shallow sites and a $10 \%$ increase in woody cover for the deep sites, would result in a $35 \%$ decrease in water yield from the 1990 levels (Table 1). Although this scenario represents one extreme of the spectrum, it may not be far from possible realities in some areas of the Edwards Plateau where large ranches are being subdivided into smaller parcels. These ranchettes are used mainly for recreation and their owners tend to be less interested in brush management (Thurow et al. 2000).

A second scenario examined the possible effect of a hypothetical publicly funded brush management cost-share program designed to increase water yield (Thurow et al. 2000). It required that ranchers clear enrolled land to $3 \%$ woody cover and maintain that cover for a 10 -year period. The government payment associated with the cost-share was calculated so that the brush management effort would result in zero net financial cost to the rancher. The ranchers who participated in a survey were willing to enroll $40 \%$ of their land to be managed at $3 \%$ brush cover (Thurow et al. 2000). Assuming $40 \%$ of the land in each range site with the least woody cover were enrolled and the woody cover for the rest of the land remain unchanged, this scenario would increase water yield by $43 \%$ over 1990 level (Table 1). These results suggest that brush management has the potential to dramatically alter water yield.

\section{Spatial distribution of Brush Management: Water Yield vs. Forage Production}

Benefits in water yield and forage production from brush management may differ in different range sites. In this study, the range sites with the highest forage production potential (Bottomland and Valley) (Redeker et al. 1998) had gentler slopes (1 to $5 \%$ ) and deeper soil resulting in greater soil water storage potential; therefore, these sites had the lowest water yield potential. The range sites with relatively low forage production potential (Low Stony Hill and Shallow) had steeper slopes (3 to $12 \%$ ) and shallower soil resulting in higher inherent water yield potential (Fig. 4). Reducing the woody cover to $3 \%$ on a Low Stony Hill range site would generate 4.8 times more water yield than doing the same on a Bottomland range site. If there is no specific structure in a cost-share program on range site distribution of the enrolled land, it is likely that more low water yield potential (high production potential) land and less high water yield potential (low production potential) land will be enrolled in the program. If the second scenario were modified (a third scenario) to enroll $40 \%$ of land in the Cusenbary Draw in range sites with the highest forage production potentials (Bottomland, Valley, and then Shallow), it would increase water yield by $50 \%$ over the 1990 level (Table 1). A fourth scenario that enrolls $40 \%$ of land in the Cusenbary Draw in range sites with the highest water yield potentials (Low Stony Hill and then Shallow), would increase water yield by $100 \%$ over the 1990 level (Table 1). The same amount but different spatial distribution of brush management efforts in these 2 scenarios would result in a $50 \%$ difference in water yield.

Population increases are expected to place increasing demands on natural resources, including the surface and subsurface freshwater supplies. These increased demands for freshwater supplies in arid and semi-arid areas are often dependent on rangeland water yield. Incentive programs, such as the publicly funded cost-share program examined by Thurow et al. (2000) have the potential to encourage vegetation management in a way that could increase water yield substantially. Range site-specific woody cover-ET regression curves, developed based on hydrologic model simulations, can be a useful tool for considering the estimated water yield associated with brush management, and a useful component to evaluate trade-offs between benefits in water yield and range production. Such consideration will aid improvement of policy structure. This approach, coupled

Table 1. Woody cover and water balance of the Cusenbary Draw basin for 1990 and 4 scenarios evaluated using woody cover-ET regression curves developed from SPUR-91 hydrologic model simulations (simulated mean precipitation $501 \mathrm{~mm} / \mathrm{yr}$ ).

\begin{tabular}{|c|c|c|c|c|c|}
\hline & \multirow[t]{2}{*}{1990 cover } & \multirow{2}{*}{$\begin{array}{c}\text { No brush } \\
\text { management over } \\
35 \text { years }{ }^{1}\end{array}$} & \multicolumn{3}{|c|}{$\begin{array}{l}\text { Variations of the revenue neutral brush management } \\
\text { program (Thurow et al. 2000) with emphasis on: }\end{array}$} \\
\hline & & & No preference ${ }^{2}$ & Forage production $^{3}$ & Water yield $^{4}$ \\
\hline Overall woody cover (\% of basin) & $23.6 \%$ & $29.5 \%$ & $21.7 \%$ & $17.6 \%$ & $17.3 \%$ \\
\hline Interception loss (mm/yr) & 99.9 & 148.9 & 109.5 & 90.2 & 87.9 \\
\hline Total ET (mm/yr) & 482.7 & 489.1 & 474.9 & 473.6 & 464.4 \\
\hline Water yield (liter/ha/yr) & 182,531 & 119,070 & 260,606 & 274,477 & 365,541 \\
\hline$\%$ difference from 1990 water yield & $0 \%$ & $-35 \%$ & $43 \%$ & $50 \%$ & $100 \%$ \\
\hline
\end{tabular}

5\% woody cover increase in Shallow and Low Stony Hill and 10\% in Deep Divide, Bottomland, and Valley range sites.

${ }^{2}$ Woody cover is reduced to $3 \%$ on $40 \%$ of the land in each range site with the lowest woody cover; and remains unchanged on the rest of the land.

${ }^{3}$ Woody cover is reduced to $3 \%$ on $40 \%$ of the land with highest forage production potentials; and remains unchanged on the rest of the land.

${ }^{4}$ Woody cover is reduced to $3 \%$ on $40 \%$ of the land with highest water yield potentials; and remains unchanged on the rest of the land. 
with remote sensing based woody cover assessment and GIS analysis, can make practical, spatially explicit brush management planning and monitoring at large watershed and regional-scales possible.

There are other concerns associated with increasing water yield through brush management. Spatial patterns of vegetation distribution at the landscape or field scales can have significant effects on the surface hydrologic process and soil erosion (Wu et al. 2000). The carrying capacity and lease value of the land for livestock grazing and/or hunting (Rollins et al. 1988, Thurow et al. 2000) can be enhanced or altered by manipulation of the density and spatial patterns of woody species. Endangered species needs (Keddy-Hector 1992) must also be considered as well as the aesthetic values of the landowner (Rowan et al 1994). Although it is beyond the scope of macro-scale strategic planning process, it is important to stress the needs of meso-scale research and tactical planning practice to address landscape or field-scale patterning of vegetation and their interaction with hydrologic process to minimize soil erosion. Simulation models combined with GIS analysis can provide insight needed to develop spatially explicit and dynamic brush management strategies that can minimize the conflicts and sustain the provision of these multiple values and products of rangelands for generations to come.

\section{Literature Cited}

Archer, S. 1994. Woody plant encroachment into southwestern grasslands and savannas: rates, patterns, and proximate causes, $\mathrm{pp}$ 13-68. In: M. Vavra, W.A. Laycock and R.D. Pieper (ed.), Ecological implications of livestock herbivory in the west. Soc. for Range Manage., Denver, Colo.

Bosch, J.M. and J.D. Hewlett. 1982. A review of catchment experiments to determine the effect of vegetation changes on water yield and evapotranspiration. J. Hydrol. 55(1):3-23.

Carlson, D.H. and T.L. Thurow. 1992. SPUR91: Workbook and users guide. Texas Agr Exp. Sta., Texas A\&M Univ. System, MP1743, College Station, Tex.

Carlson, D.H. and T.L. Thurow. 1996. Comprehensive evaluation of the improved SPUR model (SPUR-91). Ecol. Model. 85: 229-240.

Clark, O.R. 1940. Interception of rainfall by prairie grasses, weeds and certain crop plants. Ecol. Monogr. 10:243-277.

Davis, E.A. and C.P. Pase. 1977. Root systems of shrub live oak: implications for water yield in Arizona chaparral. J. Soil Water Conserv. 32:174-180
Desai, A.N. 1992. Interception of precipitation by mesquite dominated rangelands in the Rolling Plains of Texas. M.S. Thesis. Texas A\&M Univ. College Station, Tex.

Douglass, J.E. 1983. The potential for water yield augmentation for forest management in the Eastern United States. Water Resour. Bull. 14:351-358.

Dugas, W.A., R.A. Hicks, P. Wright, and G. Lindemann. 1996. Effect of removal of Juniperus ashei on evapotranspiration and runoff in the Seco Creek watershed. In: Seco Creek Water Quality Demonstration Project. 1996 Ann. Proj. Rep. Hondo, Tex.

Eddleman, L.E. 1983. Some ecological attributes of western juniper. pp. 32-34. In: Research in range management, USDA ARS, SR-682, Washington, D.C.

ERDAS. 1997. ERDAS Field Guide $4^{\text {th }}$ Edition. ERDAS Inc. Atlanta, Ga.

ESRI. 1994. Arc-Info documentation. Environmental Systems Research Institute, Inc., Redlands, Calif.

Fuhlendorf, S.D. and F.E. Smeins. 1997. Long-term vegetation dynamics mediated by herbivores, weather and fire in a JuniperusQuercus savanna. J. Veg. Sci. 8(6):819-828.

Fuhlendorf, S.D., F.E. Smeins, and W.E. Grant. 1996. Simulation of a fire-sensitive ecological threshold: A case study of Ashe juniper on the Edwards Plateau of Texas, USA. Ecol. Model. 90(3):245-255.

Hester, J.W. 1996. Influence of woody dominated rangelands on site hydrology and herbaceous production, Edwards Plateau, Texas. M.S. Thesis, Texas A\&M Univ. College Station, Tex.

Hibbert, A.R. 1983. Water yield improvement potential by vegetation management on western rangelands. Water Resour. Bull. 19(3):375-381.

Keddy-Hector, D. 1992. Golden-cheeked warbler (Dendroica chrysoparia) recovery plan. U.S. Fish and wildl. Serv., Albuquerque, N.M. $88 \mathrm{p}$.

Maidment, D.R. 1993. GIS and hydrologic modeling, pp. 147-167. In: M.F. Goodchild, B.O. Parks and L.T. Steyaert (eds.), Environmental modeling with GIS, Oxford Univ. Press, New York, N.Y.

Merrill, L.B. and V.A. Young. 1959. Effect of drought on woody plants. Texas Agr. Progress. 5:9-10.

Owens, M.K. 1996. The role of leaf and canopy-level gas exchange in the replacement of Quercus virginiana (Fagaceae) by Juniperus ashei (Cupressaceae) in semiarid savannas. Amer. J. Bot. 83:617-623.

Redeker, E.J. 1998. Effect of vegetation on the water balance of an Edwards Plateau watershed: a GIS modeling approach. M.S. Thesis. Texas A\&M Univ. College Station, Tex.

Redeker, E.J., T.L. Thurow, and X. Wu. 1998. Brush Management on the Cusenbary Draw Watershed: History and Ramifications. Rangelands 20(5):12-14.

Richardson, C.W., E. Burnett, and R.W. Bovey. 1979. Hydrologic effects of brush control on Texas rangelands. Trans. ASAE. 22(2):315-319.
Rollins, D., F.C. Bryant, D.D. Waid, and L.C. Bradley. 1988. Deer response to different intensities of brush removal in central Texas. Wildl. Soc. Bull. 16:277-284

Rowan, R.C., H.W. Ladewig, and L.D. White. 1994. Perceptions vs. recommendations: A rangeland decision-making dilemma. J. Range Manage. 47:344-348.

Schacht, W.H. and S. Reinke. 1993. Range judging handbook for the central Edwards Plateau. Angelo State Univ. Pub. B-3, San Angelo, Tex.

Scholes, R.J. and S.R. Archer. 1997. Treegrass interactions in savannas. Annu. Rev. Ecol. Syst. 28:517-544.

Singh, V.P. (ed.) 1995. Computer Models of Watershed Hydrology. Water Resour. Publ., Highlands Ranch, Colo.

Smeins, F.E. and L.B. Merrill. 1988. Long term change in a semiarid grassland. pp. 101-114. In: Edwards Plateau vegetation plant ecological studies in Central Texas. Baylor Univ. Press, Waco, Tex.

Thurow, T.L. 1991. Hydrology and erosion. pp. 141-159. In: R.K. Heitschmidt and J.W. Stuth (eds.). Grazing Management: An Ecological Perspective. Timber Press, Portland, Ore.

Thurow, T.L. 1998. Assessment of brush management as a strategy for enhancing water yield. pp. 191-198. In: R. Jensen (ed.) Proc. of the Water for Texas Conference. Texas Water Development Board, Texas Water Resources Institute, Texas Water Conservation Association, College Station, Tex.

Thurow, T.L. and J.W. Hester. 1997. How an increase or reduction in juniper cover alters rangeland hydrology. pp. 4:9-22. In: Juniper Symposium proceedings at Texas Agricultural Experiment Station, San Angelo, Tex. Texas Agr. Exp. Sta. Tech. Rep. 97-1, College Station, Tex.

Thurow, T.L., W.H. Blackburn, and C.A. Taylor, Jr. 1988. Some vegetation responses to grazing strategies, Edwards Plateau, Texas. J. Range Manage. 41:108-113.

Thurow, T.L., W.H. Blackburn, S.D. Warren, and C.A. Taylor, Jr. 1987. Rainfall interception by midgrass, shortgrass, and live oak mottes. J. Range Manage. 40:455-460.

Thurow, T.L., A.P. Thurow, and M.D. Garriga. 2000. Policy prospects for brush control to increase off-site water yield. J. Range Manage. 53:23-31.

Wiedenfeld, C.C. and D.J. McAndrew. 1968. Soil survey of Sutton County, Texas. USDA SCS, Washington D.C.

West, N.E. 1992. Shrubs: adaptations and ecosystem functions. In: Encyclopedia of Earth System Science, Volume 4. Academic Press, San Diego, Calif.

Wight, J.R. and J.W. Skiles. (eds.), 1987. SPUR-Simulation of Production and Utilization of Rangelands: Documentation and Users Guide. USDA ARS-63, Washington, D.C.

Wu, X.B., T.L. Thurow, and S.G. Whisenant. 2000. Fragmentation and changes in hydrologic function of tiger bush landscapes, southwest Niger. J. Ecol. 88(5): 790-800. 